\title{
Mental health nurses: conceptions about professional qualification in a Psychosocial Care Center*
}

\author{
Enfermeiro em saúde mental: concepções sobre qualificação profissional em um Centro de \\ Atenção Psicossocial
}

Fabíola Lisboa da Silveira Fortes ${ }^{1}$, Maria Angélica de Almeida Peres ${ }^{2}$, Tânia Cristina Franco Santos² ${ }^{2}$ Gizele da Conceição Soares Martins'², Hercília Regina do Amaral Montenegro², Antonio José de Almeida Filho²

\begin{abstract}
Objective: analyzing the strategies adopted by mental health nurses for professional qualification in a Psychosocial Care Center. Methods: a historical-social study with written documents and interviews with ten health professionals linked to the Psychosocial Care Center. Data analysis followed chronological order of the facts, and the emerging themes were triangulated and based on concepts that support Brazilian psychiatric reforms. Results: for professional qualifications, nurses invested in participating in congresses, seminars and symposiums; conducting study groups in order to develop new practical skills for mental health some nurses participated more frequently in workshops and followed other professionals for better insertion in this new context. Conclusion: the nurses approached interdisciplinary care to reconfigure their practices, investing in intellectual empowerment and faced the challenge of transforming mental health care in a deinstitutionalized practice.
\end{abstract}

Descriptors: Psychiatric Nursing; Mental Health; History of Nursing.

Objetivo: analisar as estratégias adotadas pelos enfermeiros em saúde mental para qualificação profissional no Centro de Atenção Psicossocial. Métodos: estudo histórico-social com documentos escritos e entrevistas com dez profissionais de saúde vinculados ao Centro de Atenção Psicossocial. A análise dos dados seguiu uma ordem cronológica dos fatos, e os temas emergidos foram triangulados e fundamentados em conceitos que sustentam a reforma psiquiátrica brasileira. Resultados: para qualificação profissional, investiu-se na participação em congressos, seminários e simpósios; na realização de grupos de estudos de modo a desenvolver novas habilidades práticas voltadas à saúde mental alguns enfermeiros participaram com mais frequência das oficinas e acompanharam outros profissionais para melhor inserção naquele novo contexto. Conclusão: os enfermeiros se aproximaram do cuidado interdisciplinar para reconfigurarem suas práticas, investiram na capacitação intelectual e enfrentaram o desafio de transformar a atenção em saúde mental em prática desinstitucionalizada. Descritores: Enfermagem Psiquiátrica; Saúde Mental; História da Enfermagem.

\footnotetext{
*Extracted from the thesis “Reforma Psiquiátrica em Juiz de Fora: reconfiguração do campo da saúde mental em enfermagem (1994 - 2002)", Universidade Federal do Rio de Janeiro, 2016.

${ }^{1}$ Universidade Salgado de Oliveira. Juiz de Fora, MG, Brazil.

${ }^{2}$ Universidade Federal do Rio de Janeiro. Rio de Janeiro, RJ, Brazil. 


\section{Introduction}

In Brazil, a restructuring period of the care model began in the late 1980s, when new substitute services were inaugurated such as: the Psychosocial Care Center and Centro de Convivência in São Paulo; and Psychosocial Attention Centers in Santos, with the expectation of becoming substitutes for psychiatric hospitals $^{(1-2)}$.

Considering the fundamental changes in the scenario for treating people with mental disorders, creating and expanding Psychosocial Care Centers became essential, considering that the care being sought as a substitute model should be built inside and outside mental health services. Hence, there was a need to build a support and social support network capable of welcoming users, allowing them to have new experiences $^{(2)}$. Examples of these investments were also: articulation with the Family Health Strategy, Residential Therapeutic Services, and several integrative activities that aimed at psychosocial rehabilitation of patients experiencing mental suffering.

Thus, the Ministry of Health adopted implementing Psychosocial Attention Centers as a strategy for change; open and community services aiming to improve the quality of care for people with mental disorders, and in this way to eliminate psychiatric hospitalization $^{(2)}$.

In this sense, the authorities of Juiz de Fora, a municipality located in the Zona da Mata region of the state of Minas Gerais, invested in meeting the requirements of the National Mental Health Policy and to create devices to reduce beds in psychiatric hospitals destined for hospitalizations. This initiative was guided by Bill No. 3,657, Ordinance No. 224/92(3) and the Municipal Mental Health Plan of Juiz de Fora ${ }^{(4)}$.

In relation to nursing, the methods to meet this principle unveiled great challenges, demanding efforts to cope with the unfinished, the differences, the ambiguities and the uncertainties. The 'giving of yourself' is part of that experience, and caring is part of the donation and the scientificity that is expected in this journey ${ }^{(5)}$.

Coexistence within a scenario in constant transformation began to place the nurse working in mental health to confront new and important challenges, allowing for critical analysis of the knowledge that based their professional practice to be carried out. However, the field of interpersonal relationships could not only be restricted to the nurse-patient relationship. The multiple social, cultural, political and economic dimensions should also be addressed ${ }^{(6)}$.

In Juiz de Fora, it was possible to verify the urgent need that nurses incorporated into principles of deinstitutionalization and psychosocial rehabilitation in order to deal with people with psychiatric disorders, and a long history of long hospitalizations in mental institutions. This fact became even more significant in the Casa Viva Psychosocial Care Center, which was being created in the municipality as one of the extra-hospital devices to replace the existing psychiatric hospitals in the city.

In view of the above, this study aims to analyze the strategies adopted by mental health nurses for professional qualification in the Psychosocial Care Center. Thus, it became relevant to understand the new way of caring for people with mental disorders after the Psychiatric Reform, which began to be part of the labor reality in the area of psychiatry in the extra-hospital devices, establishing actions of rupture of the paradigm that existed until then.

\section{Methods}

This is a historical-social study, which provides support for understanding past phenomena that involve collective actors inserted in a certain social dynamic. The documentary corpus of the study consisted of written documents and oral testimonies ${ }^{(7)}$. The written documents consist of a governmental, federal and municipal nature, promulgated in the course of establishing public policies associated with the Psychiatric Reform. Written documents also included reports from the National Conferences on Mental 
Health, published in a virtual space of the Ministry of Health.

In addition, written documents were also obtained from the Mental Health Coordination of Juiz de Fora, such as: online databases of the City Hall; laws; decrees; ordinances; reports; letters; and articles published in newspapers. Written sources for the reports of the Municipal Mental Health Conferences that took place in Juiz de Fora, Brazil were also searched for, in addition to the minutes and other records filed in the Municipal Health Council.

Ten professionals who worked in the process of deinstitutionalization and restructuring the Mental Health care network in Juiz de Fora-MG, Brazil were interviewed in the period when the phenomenon studied occurred. The interviews were carried out from July 2015 to January 2016, lasting from 35 to 55 minutes each in places chosen by the interviewees, with their household being predominantly chosen. Inclusion criteria for the study participants were: having integrated the team for planning, creation or implantation of the Casa Viva Psychosocial Care Center in the municipality of Juiz de Fora, state of Minas Gerais, and having preserved memory in order to ensure the quality of the information. All the interviewees (nine nurses and one psychologist) worked at the Casa Viva Psychosocial Care Center.

The study participants are identified with an initial letter corresponding to their profession and the sequence number of the interview order. The interviews were digitally recorded and later transcribed and validated by the participants through verbal and written reading and authorization for its use. The interviews were guided by a script with open questions related to the subject, such as: participation in the Psychosocial Care Center implementation process; challenges and achievements of this process; selection criteria, allocation and qualification of human resources.

Secondary sources ${ }^{(7)}$ used to analyze the data were made up of articles from scientific journals that dealt with mental health; articles that adopted con- cepts according to the proper historical methodology. For analysis of the documentary corpus, active procedures of investigating the documents were developed, adopting an independent position from the official version in order to better evidence the historical phenomenon. To ensure reliability of the results, the documentary set proper to historical research was valued, rather than just solely the documents. The chronology of the events during the period under investigation was also considered. The concepts applied in the data analysis were: deinstitutionalization and psychosocial rehabilitation $^{(8-9)}$.

These concepts are important for Psychiatric Reform as they support their principles and actions. Thus, we have deinstitutionalization being understood as a process that must affect all individuals of the society in terms of abandoning culturally widespread concepts and practices of the traditional biomedical model and psychiatric institution.

The study complied with all the formal requirements contained in national and international standards for studies involving human beings.

\section{Results}

Based on the consolidation of the Casa Viva Psychosocial Care Center in Juiz de Fora, the need for transformations in the care practices resulting from the process of psychiatric reform became evidenced, which were characterized by actions that led to constructing a comprehensive care model for the health of people with mental disorders. In Juiz de Fora, the Casa Viva Psychosocial Care Center gave rise to a proposal to reorganize the psychiatric care model, which until then was based on the institution model.

This new psychosocial space was created with the intention of creating a new environment in which the person with a mental disorder could feel welcomed, valued, representing a place for promoting encounters, solidarity and affection. The creation of this Psychosocial Care Center awakened the need for all professionals to review their concepts, methods and 
ways of dealing with mental disorders, which would make them agents of change for new understandings and attitudes within this new context of action.

It cannot be said that there was a lack of investment at the municipal and state levels in Juiz de Fora, since symposia and conferences on mental health were developed in the municipality. However, these investments did not focus on actions taken at Casa Viva Psychosocial Care Center, but rather on the whole field of mental health, which does not seem to have been identified by the professionals of the Psychosocial Care Center - in particular the nurses - as something that helped to best equip them for providing care in the Psychosocial Care Center. In addition to what was done, perhaps it would have been more productive to establish such actions within the Casa Viva Psychosocial Care Center. Some nurses reported they had not received any investment from the city for training or improvement, and this is evidenced in the following statements: The salary plans from City Hall were terrible. We had no incentive to attend congresses or take training courses in the area of mental health (NUR 1). The courses and specializations that I took were all because of my own interest and initiative; I did not receive any help (NUR 2). We did not have any help from city hall to take courses, specializations or qualifications, nothing at all and we struggled with it... (NUR 3).

The need for professional updating perceived by the nurses revealed an awareness of the importance of changes in care practice, even if this initiative is not the object of investment by the municipal public authority. The nurse became aware of the need to redefine health-disease concepts, no longer as opposing poles. It was a question of conceiving disease as a complex expression of human existence, rather than as a fracture in the continuity of its existence. An attempt in this search was participating in congresses, seminars and symposia, as can be highlighted in the following testimonies: Something that really helped me a lot were the Mental Health Conferences which took place at the national level and some local ones, which brought representatives of the Psychiatric Reform to explain what was really going to happen at that moment (NUR 4). I tried to attend some conferences here in the city. I cannot deny that there were some very competent professionals participating, and this helped me understand a little more about the process of the Psychiatric Reform (NUR 5).

From these reports, we can point out that the professional update was a complex process, since there was no planning specifically focused on the training for professionals at the Casa Viva Psychosocial Care Center. According to some participants, a strategy widely used was performing study groups, considering that this initiative enabled the nurses to develop new practical skills in the field that was emerging. This fact is evident in the following statements: ... We had a small study group with nurses, a psychologist, a social worker and a doctor for us to try to give a direction to the service; we brought books, discussed the cases of users who attended the Casa Viva Psychosocial Care Center. We were trying to understand this service (NUR 6).

Changes in the work process in the field of mental health brought forth the need to reorganize the division of this collective work, which became part of the daily routine of psychiatric nurses. Some nurses began to participate more in workshops and also to follow other professionals in order to fit into that context. These transformations were perceived in the following statements: ... I began to develop joint activities with the psychologist in the so-called "mini-team" meetings at the end of each shift, which had the purpose of discussing the occurrences of that shift, highlighting the situations considered to be difficult to cope with (ENF7). ... we started working in therapeutic workshops along with professionals from other areas, each with their specificity, and also with the participation of family members in some moments (ENF2).

Through the following testimonies, we can clearly demonstrate an attempt to accomplish teamwork being increasingly used as an important strategy in the Casa Viva Psychosocial Care Center: ... We say that the professional is no longer the psychologist, the nurse, the psychiatrist; this professional becomes a technician in mental health, they have their specificity, they need to act/work within their field of knowledge, but they also have to be open to going beyond their field of knowledge. They first need to know how to work as a team, this is what we tried to accomplish in the Casa Viva Psychosocial Care Center (PSYC1).

In analyzing the statements, we notice that during this process of adaptation and learning, the 
professionals who started working at the Casa Viva Psychosocial Care Center tried, in their great majority, to carry out interdisciplinary work. The investment of each nurse in the Casa Viva Psychosocial Care Center allowed its integration in other activities which were different from those developed in hospitals, such as: coordination of the medication group and weekend workshops; home visits together with the workshop monitor called the art studio, in which the user performed manual work at the Psychosocial Care Center.

They also participated in commissions, general meetings, team meetings and mini-team meetings at the end of each shift - with the purpose of discussing the occurrences of that shift and with an emphasis on situations considered difficult to cope with, as well as cases that demanded special attention. They also dedicated themselves to observation and coexistence with the users in the daily life of the service. These attributions of nurses can be verified in the following statements: The home visits were a moment of growth, you know, because the family would participate in that process in a way. A journey built through the new possibilities that were emerging (ENF8). At the Casa Viva Psychosocial Care Center we always tried to meet after work to discuss the most complex cases of the day, it was a way of listening to all the professionals who were taking care of that user. It was recognition of each other's work (ENF9).

\section{Discussion}

The results portray a nursing team committed to care at the Casa Viva Psychosocial Care Center and concerned with the quality of the service, pointing out facts that through the historical-social approach are presented as constitutive of a social reality. The speeches of the participants allows to write a story told by a category, which to a certain extent restricts the multifactorial relations of the mentioned interprofessional relationships and what is expected to take place in a Psychosocial Care Center.

Thus, the creation of the Psychosocial Care Center led nurses to seek updated knowledge to define a new way of treating/acting toward a person with a mental disorder. Events were carried out by the Municipal and State Health Secretariats; however, most of the nurses refer their own initiatives to increase knowledge and review their practices.

The challenges faced by nurses were related to professional dynamics within the service and they demanded to overcome the separatist perspective of the professions and to elaborate a joint approach along with other professionals - thus forming an interdisciplinary team - which is not easy, since the process of professional training imposes, as a rule, incorporating the need to establish territories of professional action $^{(8)}$. Therefore, this interaction can leave the professional feeling restless, since it requires something more from each of the constituents of the team. From this perspective, we can cite a study in which the strategies for care in the community were performed by nurses who work in mental health in partnership with social workers and psychologists ${ }^{(10)}$.

The first initiative was the creation of a study group to meet the knowledge deficit about the new care proposal, which allowed an exchange of experiences among professionals and a review of their ways of thinking about mental health care. The nurses began to act in the therapeutic groups with psychologists and created the so-called mini-teams, which would discuss and reflect on how to improve and structure the care activities at the end of shifts.

The care was slowly structured and the nurses also integrated multiprofessional workshops, in addition to the other professionals, and all were becoming aware that interdisciplinarity in Mental Health requires complicity to meet the demand of each user, which lies in the logic of a reference technician that counts on the support of all the professionals of the Psychosocial Care Center.

New care practices demand creative and reflexive knowledge, which enabled professionals to make competent inventions in their work object. Competence is understood as the intelligent ability to dialogue theory and practice, which is to theorize practices and to practice theories, without reducing one to the other. 
This leads to the capacity to propose strategies, and to participate as a critical and inventive subject ${ }^{(11)}$.

The nurses were aware of the distance between the discourse present in the specialized training in psychiatric nursing and the nursing work performed in this field. They recognized the need for a different way of perceiving and caring for a person with a mental disorder - who should not be hospitalized, contained and controlled - but rather a subject that deserves to be taken care of in their psychosocial needs ${ }^{(6)}$.

In facing the new needs and possibilities of mental health care, the nurses of the Casa Viva Psychosocial Care Center became involved with the other professionals and the care was built based on the experiences acquired in their day-to-day activities and the demands of the community served. Thus, the family was included and the activities left the physical space of the service with home visits and the care became more individualized, because they would discuss each case at the end of the day with the team.

The Casa Viva Psychosocial Care Center had its singularities in the interdisciplinary care building process and the nurse was an articulator of the care practice to overcome the so-called traditional resources, in which therapeutic communication, interpersonal relationships, and individualized care are inserted $^{(8,12)}$. The results showed a work proposal that required nurses to integrate knowledge with a diverse group of professionals ${ }^{(8)}$.

This new reality evidenced in Juiz de Fora presented limitations and overcoming in the nurses' performance, not disregarding that their professional training may have occurred in a context in which understanding the principles of psychiatric reform was still incipient; to overcome them, some strategies were developed such as: participation in seminars, conferences, symposia and study groups. These initiatives allowed for an exchange of experiences with other professionals to promote interdisciplinary work. Carrying out open-ended nursing care is not an easy task; it requires innovative alternatives and proposals, and especially sensitivity for caring gestures for it to ap- proach rather than distance the care ${ }^{(11)}$.

In spite of the complexity involved in the restructuring of nursing actions to work at Casa Viva Psychosocial Care Center, the absence of a training program aimed specifically at the professionals was verified. Acting in the field of mental health requires overcoming obstacles, refusing determinism and crystallized knowledge; for this reason the professionals must commit to the project of transforming the care by transforming themselves and consolidating the practice in a team, seeking their integration and a distribution of power ${ }^{(8)}$.

Studies developed in other countries also demonstrate the existence of professional performance without the desired qualification for care of a person with a mental disorder, able to prepare the nurses for mental health work. For example, the city of Gaza has only a few nurses and other professionals working in the area of mental health with training or specializations. There, some professionals have little contact with this knowledge during the undergraduate course, but they do not consider it sufficient to work in the mental health units ${ }^{(10)}$. In South Korea, there are also few nurses with a specialization in mental health, and most of them still work in psychiatric hospitals ${ }^{(13)}$. In Ghana, the lack of possibility for training in mental health, as well as investments in the area, directly influences the high turnover rate of professionals, which makes the accomplishment of quality therapeutic actions even more difficult, since it does not enable creation of a bond ${ }^{(14)}$.

Nurses and other health professionals should emphasize the importance of preserving their specificities while maintaining their technical differences, but considering the need to be more flexible in the division of labor. Valuing, using technical differences and integrating different knowledge contributes to enriching work ${ }^{(15)}$.

An interdisciplinary relationship requires that the disciplines involved change, and after the interaction they cannot return to what they used to be befo$\mathrm{re}^{(16)}$. To understand this new way of caring, it beca- 
me necessary to seek strategies through scientificity in order to form a professional that incorporates the principles of deinstitutionalization, translated into understanding and therapeutic attitudes directed towards the person with a mental disorder and their family.

We were able to certify that the need for training and specialization of workers for care in Psychosocial Care Center is related to a difficult process of transforming institutions into therapeutic spaces in the different locations ${ }^{(2,6)}$. On the other hand, we can observe the conflict and the difficulties that the nurses in the city of Juiz de Fora experienced in an attempt to define strategies to create a new way of acting in the Casa Viva Psychosocial Care Center in considering the model that was being demanded. This definition was still being designed through inferences and care practices already experienced by them, and while still working from the hospital model perspective. This problem demonstrates the difficulty in deinstitutionalizing this professional, which required investment in this sense.

Thus, the results of this study contribute to a preliminary evaluation of expanding the psychosocial care network, since it uncovers the ongoing process of reconfiguring professional practices that has been taking place in the historical process of a paradigm shift in mental health within a given time frame.

\section{Conclusion}

Nurses approached interdisciplinary care to reconfigure their practices, investing in intellectual empowerment and faced the challenge of transforming mental health care into a deinstitutionalized practice.

\section{Collaborations}

Fortes FLS contributed to the study conception and design, as well as data analysis and interpretation. Peres MAA, Santos TCF, Martins GCS and Montenegro HRA contributed to writing the article and relevant critical revision of the intellectual content. Fortes FLS and Almeida Filho AJ contributed to writing the article and the final approval of the version to be published.

\section{References}

1. Fonte EMM. Da institucionalização da loucura à reforma psiquiátrica: as sete vidas da agenda pública em saúde mental no Brasil. Estud Sociol [Internet]. 2012 [citado 2017 set. 17]; 1(18):119. Disponível em: http://www.revista.ufpe.br/ revsocio/index.php/revista/article/view/60/48

2. Almeida Filho AJ, Fortes FLS, Queirós PJP, Peres MAA, Vidinha TSS, Rodrigues MA. Historical trajectory of the psychiatric reform in Portugal and in Brazil. Rev Enf Ref. 2015; 20(4):117-25. doi: dx.doi.org/10.12707/RIV14074

3. Ministério da Saúde (BR). Secretaria de Atenção à Saúde/DAPE. Saúde mental no SUS: os centros de atenção psicossocial. Brasília: Ministério da Saúde; 2008.

4. Secretaria Municipal de Saúde de Juiz de Fora (BR). Plano Municipal de Saúde Mental. Juiz de Fora: Secretaria Municipal de Saúde; 1992.

5. Moreira LHO, Souza EJS, Cardoso MMVN, Silva TCS, Ferreira RGS. The formation of social reintegration strategies of the psychic suffering carrier: new directions for psychiatric nursing in Brazil. Issues Ment Health Nurs. 2014; 35(9):680-8. doi: http:// dx.doi.org/10.3109/01612840.2014.901451

6. Gruska V, Dimenstein M. Reabilitação psicossocial e acompanhamento terapêutico: equacionando a reinserção em saúde mental. Psicol Clin. 2015; 27(1):101-22. doi: http://dx.doi. org/10.1590/0103-56652015000100006

7. Teodosio SSS, Silva ER, Padilha MI, Mazera MS, Borenstein MS. Oral history and documental investigation as a research itinerary in nursing: a bibliometric study (2000-2014). Esc Anna Nery. 2016; 20(4):e20160087. doi: http://dx.doi. org/10.5935/1414-8145.20160087

8. Ibiapina ARS, Monteiro CFS, Alencar DC, Fernandes MA, Costa Filho AAI. Therapeutic Workshops and social changes in people with mental disorders. Esc Anna Nery. 2017; 2(3):e20160375 doi: http:// dx.doi.org/10.1590/2177-9465-ean-2016-0375 
9. Bandeira PM, Sousa CHP, Guimaraes JCS, Almeida Filho AJ, Peres MMA. Psychiatric nursing in integrated wards accommodating both female and male patients: a historic pioneering reform initiative implemented by the institute of psychiatry, a unit of the Federal University of Rio de Janeiro, Brazil. Issues Ment Health Nurs. 2015; 36 (10):791-8. doi: $10.3109 / 01612840.2015 .1043674$

10. Saymah D, Tait L, Michail M. An overview of the mental health system in Gaza: an assessment using the World Health Organization's Assessment Instrument for Mental Health Systems (WHOAIMS). Int J Ment Health Syst. 2015; 9(1):1-8. doi: https://doi.org/10.1186/1752-4458-9-4

11. Abreu AMM, Souza MHN, Parreira PMSD, Barroso TMMDA. Profile of consumption of psychoactive substances and its relationship to sociodemographic characteristics: a contribution to a brief intervention in primary health care, Rio de Janeiro, Brazil. Texto Contexto Enferm. 2016; 25(4):2-9. doi:http://dx.doi.org/10.1590/010407072016001450015

12. Almeida Filho AJ, Queirós PJP, Rodrigues MA. Psychosocial rehabilitation in assisted housing in Brazil and Portugal. Texto Contexto Enferm. 2016; 25(1):e0770015. doi: http://dx.doi. org/10.1590/0104-07072016000770015
13. Roh S, Lee S-U, Soh M, Ryu V, Hyunjin K, Jung WJ, et al. Mental health services and R\&D in South Korea. Int J Ment Health Syst. 2016; 10:45. doi: http://dx.doi.org/10.1186/s13033-016-0077-3

14. Agyapong VIO, Osei A, Farren CK, McAuliffe E. Factors influencing the career choice and retention of community mental health workers in Ghana. Hum Resour. 2015; 13:56. doi: http:// dx.doi.org/10.1186/s12960-015-0050-2

15. Thornicroft G, Deb T, Henderson C. Community mental health care worldwide: current status and further developments. World Psychiatry. 2016; 15(3):276-86. doi: http://dx.doi.org/10.1002/ wps. 20349

16. Souza ACS, Ribeiro MC. A interdisciplinaridade em um CAPS: a visão dos trabalhadores. Cad Ter Ocup. 2013; 21(1):91-8. doi: http://dx.doi. org/10.4322/cto.2013.013 